https://doi.org/10.18485/iipe_cpti.2020.ch10

\title{
MOGUĆNOSTI I PERSPEKTIVE SAVREMENE EVROPSKE KRAJNJE LEVICE
}

\begin{abstract}
Nemanja KOSTIĆ1
Apstrakt: U članku se razmatra pitanje uloge, položaja i delatnog potencijala krajnje levičarskih grupa, organizacija i ideja u kontekstu savremenih evropskih političkih tokova. U uvodnom delu izlaganja postavljeno je teorijsko određenje pojma krajnje levice, ukotvljeno u tradiciji sadržinskog poimanja levice $\mathrm{i}$ desnice. U drugom delu rada, u cilju podrobnijeg razumevanja problema iz naslova, dat je kratak istorijski prikaz najekstremnijih nasilnih vidova delanja i organizovanja krajnje levo orijentisanih aktera u Evropi tokom 70-ih i 80-ih godina XX veka, sa osvrtom na neke od najuticajnijih i najaktivnijih grupacija tog tipa u spomenutom periodu, poput italijanskih "Crvenih Brigada" (Brigate Rosse) i zapadnonemačke "Frakcije Crvene armije" (Rotte Arme Fraktion). U nastavku, pružen je sumarni pregled razvoja i preoblikovanja krajnje levih politika nakon pada Berlinskog zida i sloma Sovjetskog Saveza. Zaključno, ističe se da su pomenuti geopolitički lomovi i promene, praćeni snažnim posledičnim zaokretom epohalne svesti udesno, u najvećoj mogućoj meri doprineli gotovo potpunoj marginalizaciji i pasivizaciji krajnje levice (a posebno njenog najekstremnijeg krila) u savremenim evropskim društvima, te da je delatni potencijal ozbiljnijeg ugrožavanja neoliberalnog kapitalističkog poretka sa ove idejno-političke pozicije (još uvek) relativno zanemarljiv.

Ključne reči: krajnja levica, desnica, politički ekstremizam, političko nasilje, neoliberalni kapitalizam.
\end{abstract}

\section{Uvodna razmatranja}

Slavni nemački dramski pisac Bertolt Breht (Bertolt Brecht) u svojoj "Operi za tri groša" postavio je pitanje - "Šta je pljačka banke naspram osnivanja banke?". Ova, u levičarskim krugovima danas već pomalo pomodna replika, čini se, predstavlja dobar šlagvort za razmatranje

\footnotetext{
${ }^{1}$ Autor je asistent na Odeljenju za sociologiju Filozofskog fakulteta u Beogradu, e-mail: nemmanja@gmail.com
} 
pojedinih problema koje nameravamo osvetliti u ovom radu, budući da $u$ sebi, u pojednostavljenom obliku krilatice, sažima neke od bitnih dilema i pitanja koja su se tokom praktično čitavog XX stoleća javljala među određenim zagovornicima levičarskih ideja prilikom oblikovanja njihovog odnosa prema kapitalističkoj državi. Naime, načelno antikapitalističko stanovište koje, kao što ćemo videti, predstavlja minimalni zajednički imenilac krajnje raznorodnih struja unutar šire shvaćenog levog pokreta i misli, i na ideološkom i na praktično-političkom planu, meandriraće, između ostalog, i kroz različito pružanje odgovora na Brehtovo pitanje. Drugim rečima, iako u konačnici svim levo orijentisanim akterima na srcima i u umovima leži isti cilj, povezan sa ukidanjem kapitalističkog društvenoekonomskog poretka (tzv. „bankokratija“, na koju je ciljao Breht, samo je jedno u nizu ružnih lica ovog eksploatatorskog sistema u levičarskoj perspektivi), poželjna sredstva i metodi borbe koji imaju poslužiti u ostvarenju tog cilja drastično se mogu razlikovati. ${ }^{2}$

Uopšteno govoreći, pitanje zauzimanja taktičkog i praktičnog odnosa prema buržoaskoj, kapitalističkoj državi i njenim pojedinačnim aparatima, na levici je neretko dovodilo do produbljivanja raznovrsnih idejnih i praktično-političkih rascepa i vododelnica, te se $\mathrm{u}$ tom smislu prvi zadatak našeg istraživanja najpre odnosi na pokušaj teorijskog određenja samog pojma levice, uz poseban naglasak na krajnju levicu i njene radikalne i ekstremne oblike, koji predstavljaju glavni predmet ovog rada. U tom cilju, čitaocima će ukratko biti predočene dve ključne perspektive i tradicije proučavanja idejno-političke podele na levicu i desnicu - sadržinska/ strukturna i formalistička/instrumentalistička - budući da od odabira teorijske pozicije u najvećoj mogućoj meri zavisi i poimanje pojmova o kojima će biti reči u našoj analizi. U drugom delu izlaganja, pokušaćemo da letimično ukažemo na neke od osnovnih društveno-istorijskih karakteristika ključnog perioda oblikovanja krajnje levih politika nakon Drugog svetskog rata, sa fokusom na razdoblje od kraja 60-ih do kraja 80-ih godina XX veka u kapitalističkom delu Evrope, kada pod uticajem različitih, kako unutrašnjopolitičkih, ali i širih epohalnih turbulencija i previranja, dolazi do porasta nasilnih, ekstremističkih manifestacija levičarskog aktivizma na tlu

\footnotetext{
${ }^{2}$ Mnogobrojne razlike i nesuglasice među levičarskim strujama koje se odnose na viziju poželjnog društva, kao neizostavni deo svake ideologije uopšte, ovom prilikom moramo ostaviti po strani.
} 
evropskog kontinenta. Kratak prikaz delovanja organizacija, poput italijanskih "Crvenih Brigada“ i zapadnonemačke „Frakcije Crvene armije“, poslužiće nam u tom smislu kao mala (ovlašna i nipošto iscrpna) pokazna ilustracija pomenutih promena $u$ važnim pojedinačnim evropskim društvima. Naposletku, imajući u vidu krupne geopolitičke lomove koji su nastupili nakon pada Berlinskog zida 1989. godine, kao i sloma Sovjetskog Saveza dve godine docnije, pokušaćemo da protumačimo ona preoblikovanja koja su zadesila krajnju levicu u periodu izraženije konsolidacije neoliberalnog kapitalističkog poretka, kada pod uticajem snažnog zaokreta epohalne svesti udesno ova politička struja ulazi u defanzivnu fazu svog delovanja, što je za posledicu imalo relativno dugotrajnu marginalizaciju i pasivizaciju krajnje levice u Evropi, a posebno njenog ekstremnog krila. Istovremeno, razmatrajući položaj pojedinih, politički relativno uspešnih evropskih levih grupacija, ukazaćemo na neke delatne mogućnosti i perspektive ove idejno-političke porodice u bližoj budućnosti.

\section{Teorijsko određenje pojma krajnje levice}

U cilju valjanog teorijskog određenja krajnje levice, neophodno je najpre predstaviti opštu definiciju njenog najbližeg rodnog pojma, tj. samog pojma levice. U tom smislu, kako navodi Jovo Bakić, dva osnovna shvatanja idejnopolitičke podele na levicu i desnicu u savremenoj društvenoj nauci mogu se označiti kao formalističko/instrumentalno/funkcionalističko i sadržinsko/ strukturno. ${ }^{3}$ Ukratko rečeno, formalističko poimanje ove dvočlane tipologije, iako zagovara njen značaj $\mathrm{u}$ iskustvenim istraživanjima, samu podelu shvata na "teorijski ispražnjen, tj. formalan i instrumentalan način, te se njena funkcija svodi uglavnom na redukciju haotične političke stvarnosti, dok se povezanost ideoloških opredeljenja i objektivnog, na zajedničkom društvenom interesu zasnovanog, društvenog položaja posebnih društvenih grupa, ne uzima kao predmet vredan istraživanja“ ${ }^{4}{ }^{4}$ Naime, prema formalističkom poimanju teorijsko značenje pojmova levica i desnica ne postoji - „ono je proizvod konkretno-istorijske društvene konvencije

\footnotetext{
${ }^{3}$ Usled nedostatka prostora, ovde ostavljamo po strani ona stanovišta koja načelno osporavaju postojanje ili značaj ideološkog razlikovanja levice i desnice u savremenom svetu.

${ }^{4}$ Jovo Bakić, Evropska krajnja desnica 1945-2018, Clio, Beograd, 2019, str. 21.
} 
uspostavljene između politikologa, stranačkih vođstava i birača, što u određenom društveno-istorijskom kontekstu treba uvek nanovo utvrđivati; ono što je najvažnije jeste da građanstvo 'prepoznaje' i usvaja ovu dihotomiju u cilju razumevanja i tumačenja političkog delanja, a funkcija međusobnog opštenja i pravljenja političkog sistema razumljivim svim učesnicima političkog života upravo jeste i najznačajnija“.

Na drugoj strani, u okviru sadržinskog ili strukturnog poimanja, koje prihvatamo u ovom radu, od Francuske revolucije 1789. do danas, analitički se mogu prepoznavati jasno ideološki određena jezgra levice i desnice, bez obzira na promenu društveno-istorijskih okolnosti i konkretnih datosti pojedinačnih društava. Naime, načelno i uopšteno govoreći, kroz odnos prema vrednosti jednakosti prelama se i političko razlikovanje levice i desnice. U tom smislu, politički filozof Norberto Bobio (Norberto Bobbio), jedan od najistaknutijih zastupnika sadržinskog poimanja navedenih pojmova, ističe da se na levoj strani političkog spektra nalaze oni koji smatraju da su ljudska bića više jednaka nego nejednaka, a na desnoj oni koji drže da su ljudi više nejednaki nego jednaki - „nema levice bez vere u jednakost svega što nosi ljudski lik i nema desnice bez vere u opravdanost društvene hijerarhije ${ }^{\text {" }}{ }^{6}$ Istorijski posmatrano, pomenuti odnos političkih aktera prema vrednosti jednakosti, na konkretnijem planu od 1848. godine do danas, kristalisaće se kroz odnos prema kapitalizmu, kao društvenoekonomskom poretku koji nužno proizvodi društvene nejednakosti. Kao što je u uvodnim rečima našeg izlaganja naznačeno, načelno antikapitalističko stanovište predstavlja najmanji zajednički imenilac levičarskog političkog stava i angažmana, dok se putevi dolaska do željenog cilja - ukidanja kapitalističkog sistema - mogu značajno razlikovati, te se u tumačenju ovih "puteva“ nalazi i osnov za razlikovanje raznorodnih struja na levoj strani političkog spektra. Tako, Bakić navodi da se „u odnosu na ciljeve i sredstva koja se primenjuju u borbi protiv kapitalizma radi ostvarenja jednakosti, mogu razlikovati sledeći levičarski pokreti: 1) na krajnjoj levici anarhisti i komunisti (među kojima su istorijski postojale razlike između - od levih ka desnima - polpotista, maoista, trockista, staljinista, titoista, luksemburgista, evrokomunista) koji ne prezaju od revolucionarnog nasilja i privremenog ukidanja ili ograničavanja ljudskih

\footnotetext{
${ }^{5}$ Ibid., str. 23.

${ }^{6}$ Ibid., str. 25-26.
} 
sloboda - anarhisti, luksemburgisti i evrokomunisti su, međutim, najprivrženiji neophodnosti povezivanja socijalizma i demokratije, shvaćene na sadržinski, tj. društveno-ekonomski a ne formalno-proceduralistički način; fizičkog ili pravno-političkog uklanjanja klasnog neprijatelja; ukidanja kapitalističkih društveno-ekonomskih odnosa i stvaranja socijalizma odlikovanog nekom merom društveno-ekonomske jednakosti; 2) radikalni levičari, socijalisti koji, iako ne spore da je revolucionarno nasilje nekad neophodno, ipak smatraju da je ono tek ultima ratio u posebnim društvenoistorijskim prilikama, dok prihvataju parlamentarne metode borbe u cilju osvajanja vlasti na izborima i potonjeg revolucionisanja proizvodnih odnosa; 3) umereni levičari reformisti, tj. socijalni demokrati pre pada Berlinskog zida, iako su prihvatali parlamentarni način političke borbe kao jedini dozvoljeni, smatrali su da je kapitalizam neophodno reformisati sledeći kejnzovske mere, u 'državu socijalnog staranja' i pune zaposlenosti koja ublažava društveno-ekonomske nejednakosti proizvedene na tržištu i priprema teren za prelazak u socijalizam, kada društvo postane za to zrelo".

Imajući u vidu prethodno napisano, reklo bi se da je u okviru leve idejno-političke krajnosti, makar na analitičkom planu, moguće razlikovati njeno radikalno i ekstremno krilo, pri čemu je jedan od ključnih osnova za uočavanje te razlike povezan sa odnosom delatnika prema upotrebi fizičkog nasilja kao opravdanog sredstva političke borbe. S tim u vezi, moramo imati na umu i često nekritičku i neselektivnu upotrebu pojma ekstremizam, kako u publicističkoj, tako i u naučnoj literaturi, koja neretko može imati funkciju održanja i odbrane postojećeg političkog poretka kao jedinog legitimnog. Tako uticajni politikolozi, kao što su Luk Marč (Luke March) i Kas Mude (Cas Mudde), iako prihvataju postojanje razlike između levog radikalizma i ekstremizma, smatraju da se differentia specifica potonjeg ne nalazi u sklonosti ka upotrebi nasilja kao sredstva političke borbe, već u odbacivanju bilo kakvog kompromisa sa demokratijom, pri čemu se pod pojmom demokratije podrazumeva tzv. „liberalna demokratija“, kao dominantni oblik političkog sistema u savremenoj Evropi. Pomenuti autori, reklo bi se, sasvim ispravno određuju radikalizam kao ideološku i praktičnu težnju ka korenitoj promeni političkog i društvenog sistema. Međutim, na drugoj strani, prema njihovom mišljenju, ekstremizam prvenstveno podrazumeva ideološko i praktično protivljenje demokratskim vrednostima i praksama, pri čemu

${ }^{7}$ Ibid., str. $27-28$. 
sklonost ka nasilju može, ali ne mora, nužno postojati, te se u konačnici ekstremizam može odrediti kao antidemokratski per se, dok je za radikalizam karakteristično samo protivljenje liberalnoj demokratiji, ali ne i demokratiji uopšte. ${ }^{8}$ Ovakvo određenje ekstremizma, a posebice levog ekstremizma, čini se nedostatnim iz najmanje dva razloga. Prvi se sastoji u nepotpunom i maglovito određenom pojmu demokratije koja se, ako ne $\mathrm{u}$ potpunosti na teorijskom, onda na analitičkom nivou izjednačava sa pojmom "liberalne demokratije“, pri čemu se gubi iz vida da se različite struje unutar krajnje levice, koje načelno zagovaraju primenu revolucionarnog nasilja, istovremeno načelno mogu zalagati za različite vidove neposredne demokratije (već su pomenuti anarhisti, luksemburgisti i evrokomunisti). Drugi razlog se sastoji u hladnoratovskom taktičkom, konjunkturno uslovljenom i privremenom odbacivanju revolucionarnog nasilja kao glavnog sredstva političke borbe među određenim etabliranim komunističkim grupacijama u kapitalističkom delu Evrope, što je, između ostalog, za posledicu imalo javljanje istinski ekstremističkih, nasilnih odgovora na političke izazove upućene krajnjoj levici na ovom području od kraja 60-ih godina XX veka, o čemu će biti više reči u nastavku izlaganja. Prema tome, čini se opravdanim prihvatanje prvopomenutog, užeg i preciznijeg određenja političkog ekstremizma, kao onog vida političke borbe koji пužno podrazumeva upotrebu nasilnih sredstava i metoda $\mathrm{u}$ ostvarenju postavljenih ciljeva.

\section{Evropska krajnja levica od 1968. do pada Berlinskog zida}

Spuštanje "gvozdene zavese" i učvršćivanje bipolarne podele sveta nakon završetka Drugog svetskog rata označili su, između ostalog, i početak nove epohe razvoja i preoblikovanja levice u kapitalističkom delu planete. Ovaj proces poseban zamajac dobija od druge polovine 60-ih godina XX veka, u periodu kada stasavaju i političku zrelost dostižu pripadnici tzv. generacije „bejbibumera“, koji će pred prethodno etablirane političke snage

\footnotetext{
${ }^{8}$ Luke March and Cas Mudde, "What's Left of the Radical Left? The European Radical Left After 1989: Decline and Mutation", Comparative European Politics, No. 3, 2005, pp. 24-25.

Luke March, "Problems and perspectives of contemporary European radical left parties: Chasing a lost world or still a world to win?", International Critical Thought, Vol. 2, No. 3, 2012, p. 316.
} 
(i leve i desne) stupiti sa sasvim novim zahtevima i sa sasvim drugačijih pozicija. Kako navodi britanski istoričar Džef Ili (Geoff Eley), vizija budućnosti novih generacija levičara bila je posve drukčija od one koju su negovali i baštinili njihovi idejno-politički prethodnici - „participacija i direktna demokratija; feminizam, rodne razlike i politika seksualnosti; mir i ekologija; rasizam i imigraciona politika; komunalna uprava i lokalna demokratija; muzika, kontrakultura i politika zadovoljstva; građenje svesti i politika ličnog - to su bile teme koje su tokom 70-ih i 80-ih nadahnjivale mlađu generaciju levičara. Za generaciju iz 1945. takve preokupacije bile su jednostavno nepojmljive, i posledice tog sukoba promenile su levicu iz temelja".

Često se i uobičajeno u literaturi 1968. godina označava kao važna prekretnica, kako u socijalnoj i političkoj istoriji XX stoleća uopšte, tako i u razvoju levičarskih ideja i pokreta. Globalna društvena klima i ambijent stvoren tokom druge polovine 60-ih godina, kao što ćemo na pojedinim konkretnim primerima videti u narednim redovima, posledično su snažno uticali i na oblikovanje militantnog levičarskog ekstremizma u Evropi, zaodenutog u novo ruho tzv. „urbane gerile“. Čitav niz značajnih događaja i procesa koji su se odvijali širom planete, zgusnutih u nekoliko burnih godina, inicirali su nemale promene na svetskoj i evropskoj političkoj pozornici. Tako je kubanski vođa Fidel Kastro (Fidel Castro) proglasio 2. januara 1968. „Godinu herojske gerile“, u čast stradalog Ernesta Če Gevare (Ernesto Che Guevara), koji će postati verovatno najprepoznatljivija levičarska ikona u narednim godinama i decenijama, a Međunarodni Kongres kulture osnažio je među levičarima oduševljenje kubanskom revolucijom. Istovremeno, i zbivanja u Istočnoj Aziji privlačila su znatnu pažnju maoistička kineska Kulturna revolucija (najintenzivnija u periodu 19661969), studentski protesti u Japanu usmereni protiv prisustva vojnih snaga SAD u ovoj zemlji, kriza američke politike tokom Vijetnamskog rata - bili su samo neki od istaknutih činilaca svetske politike koji su imali znatnog odjeka i na evropskoj levičarskoj sceni. Džef Ili, pritom, dobro primećuje da su pobrojani događaji i procesi imali naročit uticaj na evropski omladinski i studentski radikalizam, koji je od 1968. postao izrazito internacionalistički, nadahnut nezapadnim revolucionarnim pokretima i gnevom zbog kontrarevolucionarnog delovanja SAD, pri čemu su političke promene

\footnotetext{
${ }^{9}$ Džef Ili, Kovanje demokratije: istorija levice u Evropi, 1850-2000, Fabrika knjiga, Beograd, 2007, str. 455.
} 
koincidirale sa kulturnim - „svet se smanjio, u praktičnom smislu zahvaljujući mogućnosti putovanja i komunikacijama, a u kulturnom zahvaljujući širenju istih ukusa i stilova. Ključnu ulogu imala je televizija. Događaji u Sajgonu - ili Parizu, Pragu i Čikagu - mogli su se istovremeno gledati u studentskim kafićima i klubovima u Londonu, Stokholmu, Rimu, Amsterdamu ili Zapadnom Berlinu“ ${ }^{10}$

U tako „zbijenom“ svetu nije bilo potrebno previše vremena za prelivanje uzburkanih strasti među radikalizovanom evropskom omladinom sa obe strane "gvozdene zavese“. Praško proleće, studentski protesti u Poljskoj ili Jugoslaviji, na jednoj strani, kao i omladinske pobune i fizičko sukobljavanje sa policijom na univerzitetima širom Španije, Italije, Velike Britanije, Francuske ili Zapadne Nemačke, na drugoj, jasno su nagoveštavali pojavu novih, katkad ekstremnih i nasilnih odgovora i reakcija na novonastale prilike i različite spoljne i unutrašnje pritiske. Pred novi, mladi naraštaj evropskih levičara postavljen je dvojaki zadatak - trebalo je raskrstiti sa još uvek živim i prisutnim autoritarnim nasleđem prošlosti, čiji su se nosioci nalazili među generacijom njihovih roditelja, a istovremeno je bilo potrebno prevladati pretpostavljenu učmalost i letargiju prethodno etabliranih levičarskih snaga, oličenih u starim komunističkim i socijaldemokratskim partijama, koje su, učaurene u postojeće okoštale političke forme i procese, $\mathrm{u}$ očima mladih mogle predstavljati smetnju i prepreku u ostvarenju pravednijeg društva jednakosti - „radikalna omladina se suočila s vladajućim politikama - desničarskom i levičarskom - ušančenim u ratna i posleratna iskustva. Pobuna mladih bila je antipatrijarhalna - usmerena protiv vlasti očeva u porodici, ali i protiv dugovečnih političkih autoriteta, oličenih u vladajućoj gerontokratiji Adenauera (rođenog 1876), De Gola (1890), Franka (1892) i Makmilana (1894)“ - dok je istovremeno, kako Ili takođe navodi, stara antifašistička generacija, koja je Drugi svetski rat dočekala u zrelim godinama i sada predvodila komunističke i socijaldemokratske partije, zauzvrat prezirala studentsku levicu, te je u tom duhu Edvard Šort (Edward Short), ministar obrazovanja u laburističkoj vladi 1968, o omladinskoj pobuni govorio sledeće - „ti ljudi nisu socijalisti. Nisu čak ni čestiti marksisti. To je nova vrsta anarhista, drugačija od onih hrabrih ljudi koje su mnogi od nas poznavali... To su razbojnici koji samo žele da

${ }^{10}$ Ibid., str. 456-457. 
unesu pometnju u društvo. Njihova oružja su laži, klevete, ocrnjivanje, zastrašivanje, a odskora i fizičko nasilje " ${ }^{11}$

Ipak, bunt generacije „šezdesetosmaša“, kratkoročno posmatrajući konkretno postavljene ciljeve, pretrpeo je poraz. Kako Ili ističe, u Francuskoj De Gol nije srušen, žestoke studentske pobune u Zapadnoj Nemačkoj i Italiji doživele su neuspeh, protesti protiv Vijetnamskog rata nisu pokolebali vlade u njihovoj nekritičkoj podršci politici Sjedinjenih Država, Frankov režim u Španiji je opstao, dok je u socijalističkom delu Evrope reformski čehoslovački komunizam nestao, a poljski i jugoslovenski studentski pokreti bili su potučeni. ${ }^{12}$ Izjalovljenje nada i očekivanja pomenute generacije, $\mathrm{u}$ narednim godinama, bilo je praćeno i snaženjem različitih ekonomskih i političkih trendova koji su mogli obeshrabriti radikalnije levičarske inicijative. Naime, proces deindustrijalizacije kapitalizma u Zapadnoj Evropi od kraja 60-ih, u naredne dve decenije doveo je postepeno do značajnog pada udela industrijskog proletarijata u demografskoj strukturi, što je levicu u ovim društvima moglo ostaviti bez tradicionalnog masovnog oslonca i podrške među stanovništvom. Tercijarizacija privrede uzela je maha, slabljenje sindikalizma i svojevrsna "razdrobljenost" i fragmentiranost nekadašnje radničke klase, pojačane restrukturacijom kapitalizma nakon naftne krize 1973/4, ali i prvim naznakama uspona neoliberalizma, dodatno su doveli u opasnost stare pravce levičarske politike, te je prema Ilijevim rečima, između 1970. i 1990. u Evropi nestala osnova za socijalistički pokret klasičnog tipa, oslonjen na klasnu solidarnost proletarijata. ${ }^{13}$ Međutim, iako je studentski pokret iz '68. bio kratkog veka, za sobom je uspeo ostaviti nešto dugotrajnije posledice, a jedna od njih sastojala se i u javljanju novog levičarskog ekstremizma, čiji se pojedini zagovornici nisu libili da kroz oružanu borbu pokušaju da u praksi ostvare ono što je prethodno propušteno i iznevereno - ",ako je 'izgradnja partije' bila ekstremni odgovor na amorfnost čitavog pokreta, 'oružana borba' je samo dramatizovala osećanje bespomoćnosti proisteklo iz nepokretnosti etabliranih političkih struktura. Sve širi jaz između autoriteta države i antiautoritarizma mladih s početka 70 -ih godina ironično je ohrabrio prećutne i ambivalentne simpatije prema terorizmu, na koje se ta opcija -

\footnotetext{
${ }^{11}$ Ibid., str. 474.

${ }^{12}$ Ibid., str. 486.

${ }^{13}$ Ibid., str. 514-521; 541-545.
} 
nedvosmisleno autoritarna - nužno oslanjala“ ${ }^{14}$ Kako bismo bliže razumeli pomenute tendencije, potrebno je u nekoliko rečenica predstaviti neke od osnovnih društvenih i idejno-epohalnih uslova nastanka i razvoja levičarskog ekstremizma na konkretnim, pojedinačnim primerima. U tom cilju u narednim redovima, kao što je već naznačeno, prikazaćemo delovanje zapadnonemačke „Frakcije Crvene armije“ i italijanskih "Crvenih Brigada“, koje su se nalazile među najaktivnijim i najpoznatijim levo-ekstremističkim organizacijama u narečenom periodu.

\section{Frakcija Crvene armije}

„Frakcija Crvene armije“ (nem. Rotte Arme Fraktion; skr. RAF) bila je zapadnonemačka militantna levo-ekstremistička grupacija nastala 1970. godine, od državnih vlasti i medija proglašena za terorističku organizaciju. Ne ulazeći dublje u spor oko kvalifikacija i etiketa koje su nesumnjivo svojedobno posedovale snažan polemičko-politički naboj i funkciju, na ovom mestu ćemo se prvenstveno ukratko pozabaviti društvenim i epohalnim uslovima koji su doveli do oblikovanja jedne krajnje levičarske organizacije, čiji su osnivači i pripadnici smatrali da nasilje predstavlja potpuno legitimno sredstvo u ostvarenju političkih ciljeva. Na tom tragu, potrebno je skrenuti pažnju na vladajuće političke prilike u Zapadnoj Nemačkoj. U toj kapitalističkoj državi, nastaloj nakon blokovske podele poražene Hitlerove Nemačke, nije postojala jaka komunistička partija. Zapadnonemački staljinistički usmereni komunisti, u skladu sa službeno dekretiranom idejom o potrebi odbrane od "dva totalitarizma“ (nacističkog i komunističkog), zabranjeni su 1956. godine, a na levici je hegemonsku poziciju zauzimala Socijaldemokratska partija Nemačke (SPD), koja postaje predvodnik zapadnoevropskog revizionizma već 1959, pošto odbacuje marksističko nasleđe i izražava lojalnost zapadnom konsenzusu, te je tim činom, kako Ili ispravno primećuje, levi radikalizam u ovoj zemlji dodatno odgurnut ulevo. ${ }^{15}$ U vezi sa tim, pomenuti događaji iz druge polovine 60-ih godina u Zapadnoj Nemačkoj doveli su do žestoke polarizacije između studentskog pokreta i službene levice, oličene u SPD. Radikalizovana zapadnonemačka omladina, nadahnuta antifašističkim idejama, snažno je odbacivala autoritarno nasleđe

\footnotetext{
${ }^{14}$ Ibid., str. 487.

15 Ibid., str. 556.
} 
iz bliske prošlosti, a njegove nosioce je počela prepoznavati ne samo $u$ konzervativnoj Hrišćansko-demokratskoj uniji (CDU), već i u SPD, koja krajem 1966. ulazi u Veliku koaliciju sa demohrišćanima, a na čelu ove koalicione vlade naći će se bivši nacista Kurt Georg Kizinger (Kurt Georg Kiesinger). Socijaldemokrati su, stoga, optuženi sa kompromiserstvo sa trulim, konzervativnim i autoritarnim političkim establišmentom, $\mathrm{i} u$ istom periodu studentski radikalizam se organizacijski uobličava kao Vanparlamentarna opozicija (APO) ${ }^{16}$ Jedna od razočaranih omladinki SPDa, zgrožena sklapanjem Velike koalicije, bila je i Gudrun Enslin (Gudrun Ensslin), koja će zbog tog čina napustiti SPD, da bi docnije postala jedna od osnivačica "Frakcije Crvene armije ${ }^{17} \mathrm{O}$ odnosu i stavu radikalizovane omladine prema starijoj generaciji i njenom zločinačkom ratnom nasleđu možda najbolje svedoči rečenica koja se pripisuje upravo Enslinovoj - „reč je o generaciji Aušvica - sa njima ne može biti pregovora“ ${ }^{18}$ I Ili navodi da je ulazak SPD u vlast, praćen snaženjem pomenutog antagonizma između vanparlamentarne levice i SPD, kao i državnom kampanjom usmerenom protiv terorizma i antinuklearnih protesta, posledično doveo do reakcije različitih građanskih inicijativa usmerene protiv vladinih autoritarnih sredstava, što je naposletku, između ostalog, gurnulo APO u nasilje i fragmentaciju, iz čega je proizašla i Frakcija Crvene armije. ${ }^{19}$

Iako tokom svog postojanja RAF nikada nije imao više od trideset aktivnih članova, sredstva i metodi borbe koje su praktikovali pripadnici ove organizacije (koji su, između ostalog, podrazumevali podmetanje požara i eksploziva, pljačke banaka, ubistva vladinih službenika i biznismena, otmice i stvaranje talačkih kriza), uspeli su da privuku izuzetnu pažnju javnosti na njihovo delanje. ${ }^{20}$ Osnivači RAF-a, Andreas Bader

\footnotetext{
${ }^{16}$ Ibid., str. 557.

${ }^{17}$ Leonard Weinberg, Ami Pedahzur \& Arie Perliger, Political Parties and Terrorist Groups, Routledge, London and New York, 2009, p. 25.

${ }^{18}$ Wilfried Mausbach, "America's Vietnam in Germany - Germany in America's Vietnam", in: Belinda Davis, Wilfried Mausbach, Martin Klimke and Carla MacDougall (eds), Changing the World, Changing Oneself: Political Protest and Collective Identities in West Germany and the U.S. in the 1960s and 1970s, Berghahn Books, New York and Oxford, 2010, p. 47.

${ }^{19}$ Džef Ili, Kovanje demokratije: istorija levice u Evropi, 1850-2000, op. cit., str. 559.

${ }^{20}$ Ariel Merari, "Terrorism as a Strategy of Insurgency", in: Gerard Chaliand and Arnaud Blin (eds.), The history of terrorism: from antiquity to al Qaeda, University of California Press, Berkeley and Los Angeles and London, 2007, p. 31.
} 
(Andreas Baader) i pomenuta Enslin tako su, još 1968, podmetnuli požar u poznatoj robnoj kući u Frankfurtu, čime su želeli da iskažu svoj protest protiv kapitalizma i imperijalizma. ${ }^{21}$ Budući da su se na meti napada RAFa ubrzo našli i vladini službenici, usledila je i snažna reakcija države. Tokom 1972. godine, vođstvo organizacije je "obezglavljeno“ hapšenjem Badera, Enslin i radikalne novinarke Ulrike Majnhof (Ulrike Meinhof; RAF je bio medijski poznat i kao Bader-Majnhof grupa). Hapšenju su prethodile pljačke banaka, napadi na policijske stanice, ali i na pojedine američke vojnike stacionirane u Zapadnoj Nemačkoj, kao i napadi na vlasništvo konzervativnog medijskog magnata Aksela Špringera (Axel Springer), a bilans ljudskih žrtava samo u maju 1972. iznosio je četvoro mrtvih i preko šezdeset povređenih. Mete pobrojanih činova bile su nesumnjivo ideološki određene, budući da su RAF-ovci u njima prepoznavali personifikacije kapitalizma, starog fašističkog autoritarizma i američkog imperijalizma. Ukazivanjem na slabe i ranjive tačke državnog sistema, trebalo je izazvati simpatije među širim društvenim slojevima. Međutim, stvari se nisu odvijale tako glatko, pa je nakon pomenutih hapšenja došlo do osipanja podrške RAF-u među pojedinim levičarskim intelektualcima koji su načelno podržavali ciljeve, ali ne i metode borbe koje je zagovarala ova organizacija, a model aktivizma za koji se zalagao RAF postao je prepoznat kao vid isticanja ličnog avanturizma i hrabrosti nauštrb istinskog socijalističkog političkog angažmana. ${ }^{22}$

Naravno, levičarski radikalizam u Zapadnoj Nemačkoj bio je izražen tokom 70-ih i mimo nasilnog, ekstremističkog delovanja RAF-a, te se tzv. "druga generacija“" pripadnika ove organizacije nadala da je još uvek moguće zadobiti masovniju podršku za sopstvene ciljeve. Vrhunac napetosti nastupio je tokom "Nemačke jeseni“ 1977, kada je RAF najpre kidnapovao predsednika Dajmler-Benca, šefa federacije poslodavaca i bivšeg SS oficira Hansa Martina Šlajera (Hans Martin Schleyer), a zatim izvršio otmicu Lufthanzinog putničkog aviona, zahtevajući oslobađanje svojih vođa. Zapadnonemački vojni specijalci su oslobodili taoce, a Bader, Enslin i Jan-Karl Raspe (Jan-Karl Raspe) pronađeni su mrtvi u svojim

${ }^{21}$ Marija Đorić, Ekstremna levica: ideološki aspekti levičarskog ekstremizma, Institut za političke studije, Beograd, 2016, str. 74.

${ }^{22}$ Karrin Hanshew, "'Sympathy for the Devil?' The West German Left and the Challenge of Terrorism", Contemporary European History, Vol. 21, No. 4, 2012, pp. 511-512. 
ćelijama, iako je zatvor u kome su se nalazili bio maksimalno obezbeđen. U znak odmazde, RAF je pogubio Šlajera - reč je bila o poslednjoj velikoj akciji ove organizacije, koja je manje napade (i sa znatno manje odjeka i efekta) sporadično izvodila do $1998 .{ }^{23}$ Naime, iako su članovi Frakcije Crvene armije (kao i članovi "Crvenih Brigada", o kojima će biti reči u nastavku) smatrali svoje postupke, kako Ili kaže, uzornim činovima koji treba da izazovu društvenu polarizaciju kao osnovu za opštu pobunu radničke klase, njihova strategija se pokazala nedelotvornom, pa i razornom po samu krajnju levicu, budući da je samo ojačala državnu represiju i izoštrila antirevolucionarnu reakciju. ${ }^{24}$

\section{Crvene Brigade}

"Crvene Brigade“ (it. Brigate Rosse; skr. BR) bile su italijanska militantna levo-ekstremistička organizacija, formirana 1970. godine, a osim godine osnivanja sa RAF-om je veže i percepcija od strane državnih vlasti koje su je prepoznale kao terorističku grupu. Međutim, sličnosti tu ne prestaju, te je potrebno u nekoliko rečenica izložiti društveno-istorijske okolnosti koje su dovele do pojave BR-a. Naime, italijansko posleratno društvo, kao i u slučaju Zapadne Nemačke, bilo je u znatnoj meri obeleženo neprevladanim ostacima fašističke prošlosti. Ipak, za razliku od Nemačke, Italija je tokom Drugog svetskog rata imala snažan antifašistički pokret, te je i posleratna polarizacija između antifašizma i ostataka fašističkog režima bila izraženija nego što je to bio slučaj u Nemačkoj. Naime, Italija je imala najveću komunističku partiju u kapitalističkom delu sveta, ali se, na drugoj strani, već krajem 1946. i nekadašnji fašistički borci udružuju u Italijanski socijalni pokret (MSI), koji će biti hegemon na italijanskoj krajnjoj desnici sve do ranih 90-ih godina. ${ }^{25}$

Opet, kao i slučaju odnosa između budućih članova RAF-a i nemačkih socijaldemokrata, deo mladih italijanskih komunista se nakon dešavanja iz 1968. sve otvorenije protivi „,kompromisima“ koje Italijanska komunistička partija (PCI) čini $u$ odnosu prema vladajućim konzervativnim demohrišćanima. Upravo ti radikalizovani omladinci će sačinjavati jezgro

\footnotetext{
${ }^{23}$ Džef Ili, Kovanje demokratije: istorija levice u Evropi, 1850-2000, op. cit., str. 561-562.

${ }^{24}$ Ibid., str. 610-611.

${ }^{25}$ Jovo Bakić, Evropska krajnja desnica 1945-2018, op. cit., str. 247-248.
} 
"Crvenih Brigada“, nezadovoljni navodnim ustupcima koje PCI čini prema kapitalističkom poretku. ${ }^{26}$ Naime, moglo bi se reći da su u političkoj viziji ovih budućih levičarskih ekstremista, "reformizam", "revizionizam" i "kompromiserstvo" italijanskih komunista i sindikata predstavljali najznačajniju prepreku ostvarenju revolucionarnih ideala, navodno potiskujući i gušeći potencijal razbuktavanja istinskog klasnog rata. ${ }^{27}$ Istovremeno, desničarska vlada činila je sve da kompromituje levičarske inicijative. U decembru 1969, nakon tri bombaška napada, kada je u Milanu ubijeno šesnaest, a u Rimu dvoje ljudi uz još osamnaest ranjenih, počinje, kako Ili navodi, hajka na anarhiste, iako su te zločine počinili neofašisti povezani sa Tajnom službom - „njihova 'strategija tenzije', koja je koristila reakciju protiv levice da opravda ograničavanje građanskih sloboda, uvođenje vanrednih mera, pa i državni puč, zahtevala je zamršene veze između vlade, vojske, tajne službe, poslovnih krugova, Vatikana i Mafije “28 - čime se spirala nasilja samo produžila, pa je tako maja 1974. u bombaškom napadu na antifašističkom skupu u Breši stradalo osmoro ljudi. Pre toga, 1972. godine, neofašistički MSI osvaja 8,7\% glasova na izborima, što je bio najbolji rezultat ove partije. Svi pomenuti događaji posledično izazivaju reaktivno nasilje "Crvenih Brigada" koje, Ilijevim rečima, prelaze sa propagiranja nasilja na oružane udare, počevši sa otmicom Marija Sosija (Mario Sossi), sudije iz Đenove, koji je oslobođen nakon 35 dana u aprilu 1974. ${ }^{29}$

Vrhunac dejstva BR-a svakako je povezan sa otmicom i ubistvom Alda Mora (Aldo Moro) 1978. godine. Naime, evrokomunistički vođ PCI Enriko Berlingver (Enrico Berlinguer) bio je spreman na istorijski kompromis sa demohrišćanima i njihovim liderom Morom, što je izazvalo revolt levih ekstremista okupljenih u BR. Neposredno nakon formiranja Vlade nacionalnog jedinstva, "Crvene Brigade“ su kidnapovale premijera Mora, a čitava zemlja ulazi u krizu. PCI tada odbija mogućnost bilo kakvog popuštanja pred terorističkim metodima i zahtevima, što dovodi do Morovog ubistva, te je na taj način, kako Ili primećuje, oružani

\footnotetext{
${ }^{26}$ Leonard Weinberg, Ami Pedahzur \& Arie Perliger, Political Parties and Terrorist Groups, op. cit., pp. 20-21.

${ }^{27}$ Alessandro Orsini, Anatomy of the Red Brigades: the religious mind-set of modern terrorists, Cornell University Press, Ithaca and London, 2011, pp. $42-47$.

${ }^{28}$ Džef Ili, Kovanje demokratije: istorija levice u Evropi, 1850-2000, op. cit., str. 546.

${ }^{29}$ Ibid., str. 546.
} 
revolucionarni radikalizam bio diskreditovan u očima javnosti, da bi nakon daljeg nasilja i intenzivnijeg odgovora policije terorizam počeo da opada. ${ }^{30}$ Međutim, skupa sa ekstremizmom, otupela je i oštrica radikalne levice u Italiji - PCI je postala "partija zakona i poretka“ $\mathrm{i}$ „,štit ustava“ - istovremeno povezan sa korumpiranom državom $\mathrm{i}$ interesima demohrišćana, a rezultat "velikog kompromisa“ ogledao se u slabljenju državnih privrednih pokazatelja i posledičnom padu podrške italijanskim komunistima $u$ njihovom tradicionalnom biračkom telu. ${ }^{31}$

\section{Krajnja levica u povlačenju?}

Prethodno pomenuti globalni trendovi, koji su nagoveštavali preoblikovanje kapitalizma u neoliberalnom pravcu početkom 70-ih godina XX veka, znatno većim intenzitetom nastavljeni su tokom 80 -ih, u deceniji u kojoj su svetsku političku scenu obeležile ličnosti poput Margaret Tačer (Margaret Thatcher) i Ronalda Regana (Ronald Reagan). Simbolički trijumf kapitalizma obeležio je pad Berlinskog zida krajem iste decenije, a već 1991. godine dolazi do sloma Sovjetskog Saveza, te je na taj način konačna kapitalistička pobeda nad realnim socijalizmom bila i faktički ostvarena. Svet je iznova premrežen kapitalističkim društveno-ekonomskim odnosima, a čitava levica našla se u defanzivi pred novim izazovima. „Kompromiserstvo“ za koje su mladi levičari iz evropskih kapitalističkih zemalja nekada optuživali etablirane socijaldemokratske i komunističke partije, bez preterano vešte ideološke mimikrije, sada je moglo da se nastavi. Prvi potez povukli su umereni levičari, socijaldemokrati, koji su i ranije pravili značajne ustupke u tom pravcu. Već je pomenuto da je nemački SPD još 1959. programski odustao od pojedinih značajnih marksističkih načela, a i prepiska između Branta, Palmea i Krajskog, objavljena 1976, pokazala je da su socijaldemokrati, a posebno Brant (kao vođa SPD), prestali da budu reformisti koji se nadaju preobražaju kapitalističkog u socijalističko društvo. ${ }^{32}$ Nakon sloma evropskog socijalizma, ovaj otklon od reformizma kod socijaldemokrata postao je još uočljiviji, a mnoge nekadašnje leve stranke i intelektualci počinju da pravdaju tržišna načela i logiku profita,

\footnotetext{
${ }^{30}$ Ibid., str. 549.

31 Ibid., str. 550.

${ }^{32}$ Jovo Bakić, Evropska krajnja desnica 1945-2018, op. cit., str. 28.
} 
"prelazeći“" na taj način u leve liberale, čime sebe zapravo isključuju iz okvira levice. ${ }^{33}$ Rečima Miroslava Ružice, evropska socijaldemokratija danas „ima politike i programe za žene, decu, ljude različite seksualne orijentacije, umetnike, ali ne i za radničku klasu“ ".34

Nekadašnja evropska krajnja levica našla se na znatno većem udaru novostvorenih prilika i okolnosti. Sovjetski Savez i Istočni blok su nestali, a udaljena Kina odavno je napustila „pravoverni“ maoistički put, te su šanse za uspostavljanje socijalizma postale sasvim bezizgledne. Duh nove epohe potiskivao je čitav politički spektar udesno. Kapitalizam je postao razobručen, lišen realne opasnosti od izbijanja socijalističke revolucije. Kako ističe Todor Kuljić, neoliberalizam, kao oznaka novog odnosa ekonomije i politike $u$ dobu globalizacije, u poslednjoj deceniji XX veka potisnuo je ulogu društvenih utopija, a nosioci demonizacije socijalizma podjednako su bili i liberali i konzervativci. ${ }^{35}$ Uopšteno govoreći, evropski ekstremni i radikalni levičari pretrpeli su političku marginalizaciju i fragmentaciju, pri čemu su prvopomenuti postali gotovo sasvim pasivizirani i neutralisani, bezmalo svedeni na različite neuticajne anarhističke, trockističke i maoističke sekte ("dostojni“ savremeni parnjaci RAF-a i BR-a nisu se pojavili), a potonji izborno $\mathrm{u}$ poslednjih desetak godina najbolje stoje $\mathrm{u} \mathrm{u}$ Češkoj, Grčkoj, Kipru, Nemačkoj, Rusiji i Francuskoj. ${ }^{36}$ Marč i Mude navode da se dva glavna procesa preoblikovanja, koja su zadesila ovu političku struju, mogu označiti terminima opadanje i mutacija. Opadanje se prvenstveno odnosi na situaciju u kojoj su se našle stare etablirane komunističke partije, koja je predstavljala neposrednu posledicu urušavanja Sovjetskog Saveza, kao bastiona svetskog komunizma, pri čemu se proces opadanja odvijao kroz političku marginalizaciju koja je bila praćena ublažavanjem i izmenom ideoloških stavova i retorike pod pritiskom novih okolnosti. Istovremeno, na drugoj strani, promene koje je na levici izazvao pad SSSR-a, dovele su i do mogućnosti mutacije, tj. oblikovanja šireg pokreta

\footnotetext{
${ }^{33}$ Ibid., str. 20.

${ }^{34}$ Miroslav Ružica, „Kriza i mogućnost obnove evropske socijaldemokratije“, u: Zoran Stojiljković (ur.), Levica u postkriznom kontekstu, Friedrich Ebert Stiftung i Centar za demokratiju, Beograd, 2013, str. 15.

35 Todor Kuljić, Prevladavanje prošlosti: uzroci i pravci promene slike istorije krajem XX veka, Helsinški odbor za ljudska prava u Srbiji, Beograd, 2002, str. 36.

${ }^{36}$ Jovo Bakić, Evropska krajnja desnica 1945-2018, op. cit., str. 28.
} 
nove radikalne levice, lišene stiska lagerske pravovernosti, u okviru koje su razvijeni novi idejni i taktički obrasci, koji se ogledaju u „socijalnom populizmu i modernim oblicima transnacionalne saradnje, kroz npr. Evropski parlament ili antiglobalizacijski pokret" ${ }^{37}$ Što se tiče nekadašnjih evropskih komunističkih partija, četiri glavna pravca njihovog ideološkog i organizacionog preoblikovanja nakon sloma real-socijalizma bila su: 1) odbacivanje komunističke "oznake“ i transformacija u "demokratsku levicu" (npr. finska Leva alijansa, fin. Vasemmistoliitto); 2) transformacija u klasične socijaldemokratske stranke (npr. italijanske Demokrate levice, it. Democratici di Sinistra); 3) pripajanje drugim, često ne-radikalnim partijama (npr. ulazak holandskih komunista u Zelenu levicu, hol. GroenLinks) 4) opstanak opšte komunističke usmerenosti (npr. grčki i francuski komunisti - KKE i PCF). ${ }^{38}$

Na drugoj strani, sa stanovišta perspektiva i delatnog potencijala levice u bližoj budućnosti, posebno je zanimljivo pomenuto pitanje "mutacije“ nove levičarske politike $u$ pravcu onoga što se $u$ literaturi neretko određuje inflatornim pojmom populizam. Stoga je najpre potrebno odrediti sadržaj koji se podrazumeva pod ovim pojmom, kako bismo potom utvrdili koje se, politički relativno uspešne, levo orijentisane grupacije neretko svrstavaju $\mathrm{u}$ populističke. Na ovom mestu, naime, odbacujemo dosta rašireno shvatanje populizma kao ideologije koje, kako Bakić ispravno primećuje, često ima propagandnu funkciju izjednačavanja "levog i desnog populizma", tj. leve i desne idejno-političke krajnosti, a prihvatamo određenje istog autora, koji pod pojmom populizma podrazumeva demagogiju - „kao političku strategiju i taktiku osvajanja, te čuvanja i pravdanja osvojene vlasti u političkim zajednicama zasnovanim na opštem biračkom pravu, gde se posebnim načinom političkog opštenja - naročito upotrebom osećanjima nabijenog diskursa - podilazi pretpostavljenim idealima, predrasudama ili željama većine biračkog tela posredstvom nerealnih obećanja i napada na 'moćne, bogate i korumpirane manjine', ili na 'tirane koji ugrožavaju ljudska prava i mir u svetu', kao i ukazivanjem na nepravedan odnos velikih sila ili međunarodnog sistema prema sopstvenoj političkoj zajednici, odnosno na nepravedan odnos neke lokalne

\footnotetext{
${ }^{37}$ Luke March and Cas Mudde, "What's Left of the Radical Left? The European Radical Left After 1989: Decline and Mutation”, op. cit., p. 24.

${ }^{38}$ Ibid., p. 27.
} 
sile prema nacionalnim manjinama, ili susednoj, od nje manje moćnoj, državi. Drugačije, u političkim zajednicama koje, usled opšteg biračkog prava, teže demokratskom idealu, demagogija (populizam) svojstvena je politička taktika i stil većine političara" ${ }^{39}$

Sasvim u skladu sa prethodno rečenim, a imajući u vidu široko rasprostranjenu tzv. catch-all taktiku većine relevantnih političkih delatnika, ne treba da čudi to što savremena evropska levica u predstavljanju političkog programa biračima i javnosti, za razliku od svojih idejnih prethodnika, sve manje insistira na pozitivnim ideološkim određenjima (uspostavljanje socijalizma ili komunizma), retorički smeštajući u prvi plan negativna određenja i borbeni odnos prema vladajućem poretku (alternativa, anti-neoliberalizam, anti-kapitalizam), što za cilj ima privlačenje socijalno šarolike glasačke baze nezadovoljnika aktuelnim stanjem (industrijski radnici, zaposleni u javnom sektoru, intelektualci, nezaposleni, prekarijat, radno neaktivno stanovništvo i sl). ${ }^{40} \mathrm{U}$ tom smislu, ponovno pomaljanje i oživljavanje levičarske političke inicijative na evropskoj političkoj sceni tokom poslednje decenije XXI stoleća povezano je upravo sa usvajanjem pomenute demagoške (populističke) strategije i taktike osvajanja vlasti, pri čemu je jedno od glavnih retoričkih sredstava novih, relativno uspešnih, levo orijentisanih organizacija postalo pozivanje na „narod“ (koji je shvaćen, dakle, kao skupna oznaka za politički i ekonomski obespravljene široke društvene slojeve, a ne za posebnu etničku grupu, kao u slučaju krajnje-desničarske upotrebe ovog termina) umesto na „radničku klasu“, kao tradicionalni masovni oslonac levice. Jedan od osnovnih društvenih činilaca rasta uticaja takvih organizacija svakako je bio uslovljen višegodišnjom ekonomskom krizom širom evropskog kontinenta, a posebno u pojedinim državama evropske periferije, koje su najviše pogođene visokim stopama nezaposlenosti, oštrim merama štednje i krizom javnog duga, te se tako i uspon grčke Koalicije radikalne levice (SYRIZA) i španskog PODEMOS-a (srp. „Možemo“), koji su u proteklih pet godina uzeli učešća u vlasti u svojim zemljama (obe u koalicionim vladama SYRIZA kao većinski, a PODEMOS kao manjinski partner), može tumačiti u tom svetlu. Pritom je važno napomenuti i to da neke starije "populističke"

${ }^{39}$ Jovo Bakić, Evropska krajnja desnica 1945-2018, op. cit., str. 67-79.

${ }^{40}$ Paolo Chiocchetti, The Radical Left Party Family in Western Europe, 1989-2015, Routledge, London and New York, 2017, p. 201. 
partije levičarskog usmerenja u centru EU, poput nemačke Levice (Die Linke) ili holandske Socijalističke partije (Socialistische Partij), iako zastupljene $\mathrm{u}$ nacionalnim parlamentima, nisu nikada uspele da se približe osvajanju vlasti, kao ni „Nepokorena Francuska“ (La France Insoumise), izborni savez koji je 2017. kandidovao Žana Lika Melanšona (Jean-Luc Melenchon) za predsednika Francuske (sa nešto većim uspehom, oko 19,5\% osvojenih glasova), te je moguće zaključiti da je slabiji intenzitet krize u ovom delu Evrope mogao biti jedan od činilaca neuspeha levice. ${ }^{41}$ Istovremeno, potrebno je biti svestan izuzetno ograničenih mogućnosti i izgleda na stvarno sprovođenje antikapitalističke levičarske politike na periferiji Evrope, budući da je manevarski prostor organizacija poput SYRIZA-e (koja je vlast izgubila već 2019) i PODEMOS-a značajno sužen samim (polu)perifernim položajem Grčke i Španije u svetskom kapitalističkom sistemu. Tako je, kako Kas Mude navodi, svojevrsni „Treći put“ za koji se zalagala SYRIZA morao skončati na isti način kao i „Treći put“ britanskih laburista 90-ih, faktički sveden na neoliberalnu politiku maskiranu i zabašurenu progresivnom retorikom. ${ }^{42}$ Pored toga, i levica u centralnim zemljama EU, ionako relativno slaba, a poslednjih godina suočena sa značajnim usponom krajnje desnice i postavljanjem useljeničkog pitanja kao centralnog političkog problema i teme, veoma teško može izaći na kraj sa nametnutim izazovima. Imajući u vidu poslednje rečeno, moramo imati na umu da se pred evropskom levicom (i umerenom i krajnjom) nalazi zahtevan dvostruki zadatak političkog sukobljavanja, kako sa etabliranim liberalnim i konzervativnim snagama koje stabilno stoje na braniku kapitalizma, tako i sa krajnjom desnicom koja u istom cilju, kako Bakić primećuje, ideološki uzurpira neke od starih levičarskih tekovina, poput države socijalnog staranja, pretvarajući je u ksenofobični koncept „Šovinističke socijalne politike" (welfare chauvinism), tj. socijalne politike rezervisane isključivo za etnički/rasno/religijski istovrsne. ${ }^{43}$ Predviđanje ishoda tog političkog obračunavanja nesumnjivo je nezahvalno, premda bi

${ }^{41}$ Giorgos Katsambekis and Alexandros Kioupkiolis, "Introduction: the Populist Radical Left in Europe", in: Giorgos Katsambekis and Alexandros Kioupkiolis (eds.), The Populist Radical Left in Europe, Routledge, London and New York, 2019, pp. 1-21.

${ }^{42}$ Cas Mudde, SYRIZA - The Failure of the Populist Promise, Palgrave Macmillan, 2017, p. 20.

${ }^{43}$ Jovo Bakić, Evropska krajnja desnica 1945-2018, op. cit., str. 29. 
se iz priloženog reklo da izgledi na uspeh levice u bliskoj budućnosti verovatno nisu preterano veliki.

Naposletku, treba napisati nekoliko reči o savremenom evropskom levom ekstremizmu. Naime, već je bilo pomena da današnje nasilne manifestacije levičarskog aktivizma nisu značajne iz perspektive mogućnosti iole ozbiljnijeg ugrožavanja neoliberalnog kapitalističkog poretka, te da se mahom svode na labavo povezane i uglavnom slabo vidljive anarhističke, trockističke i maoističke grupice istomišljenika. Snažno opadanje međunarodnog ugleda levice nakon pada Berlinskog zida i sloma Sovjetskog Saveza nesumnjivo je (kao i u slučajevima umerene i radikalne levice) moralo dovesti i do pada privlačnosti levo-ekstremističkih stremljenja među (studentskom) omladinom, koja je i tokom 70-ih, dok je taj korpus ideja posedovao izvestan magnetizam, bila osnovna regrutna baza ekstremne levice. Relativni izuzetak od ovog pravila donekle (naime, nasilne akcije koje sprovode najčešće su sporadične i u svega nekoliko slučajeva rezultirale su ljudskim žrtvama) predstavljaju samo pojedine grčke, španske i italijanske (uglavnom anarhističke) grupe, budući da u navedenim društvima postoji izuzetno dugotrajna i kontinuirana tradicija privrženosti levim idejama, ali i tradicija nasilnih (pa i terorističkih) pokušaja pružanja otpora kapitalističkom poretku u bliskoj prošlosti. Tako u pobrojanim državama, kako navodi Marija Đorić, porast nasilja iza kojeg stoji ekstremna levica korespondira sa rasplinjavanjem ekonomske krize 2008. godine, a u trenutno aktivne grčke grupacije tog tipa spadaju Zavera vatrenih ćelija, Revolucionarna borba i Sekta revolucionara; u Italiji su to Neformalna anarhistička federacija i Nove crvene brigade; a u Španiji maoistička organizacija GRAPO (koja postoji još od 1975) i anarhistička FAI (koja povezuje španske i portugalske anarhiste). ${ }^{44}$

\section{Zaključna razmatranja}

Osnovni zadatak našeg istraživanja sastojao se u pokušaju tumačenja perspektiva i mogućnosti krajnje levičarskih političkih snaga i ideja na tlu savremene Evrope. $\mathrm{U}$ tom cilju, $\mathrm{u}$ radu smo najpre postavili pojmovno određenje krajnje levice, ukotvljeno u teorijskoj tradiciji sadržinskog

${ }^{44}$ Marija Đorić, Ekstremna levica: ideološki aspekti levičarskog ekstremizma, op. cit., str. 170-181. 
poimanja podele političkog spektra na levicu i desnicu, u okviru kojeg se odnos delatnika prema vrednosti jednakosti posmatra kao ključni osnov idejno-političke podele. Pomenuti odnos, na konkretnijem planu, tumačen je kroz razlike $\mathrm{u}$ vrednovanju kapitalizma, kao društveno-ekonomskog sistema koji nužno proizvodi društvene nejednakosti, te je krajnja levica prepoznata kao ona idejno-politička snaga koja načelno teži relativno brzom temeljnom prevazilaženju i posledičnom ukidanju kapitalističkog poretka, sa konceptom stvaranja pravednijeg društva, zasnovanog na jednakosti među ljudima. Dalje, kroz tumačenje odnosa prema poželjnim sredstvima i metodima borbe protiv kapitalizma, analitički su izdvojene dve struje unutar krajnje levice - radikalna i ekstremna - pri čemu je kao osnov njihovog razlikovanja uzet odnos prema upotrebi nasilja u političkim sukobima. Naime, dok revolucionarno nasilje za radikalnu levicu jeste tek ultima ratio u posebnim društvenim okolnostima, za ekstremnu levicu nasilje predstavlja ključni modus operandi u antikapitalističkoj borbi.

$\mathrm{U}$ nastavku izlaganja, predstavljeni su procesi i događaji koji su, $\mathrm{u}$ periodu nakon završetka Drugog svetskog rata, snažno uticali na preoblikovanje krajnje levice u kapitalističkom delu Evrope. Pojava novog levičarskog ekstremizma tokom 70-ih godina XX veka tumačena je u svetlu promena izazvanih reakcijama na dešavanja 1968, kada radikalizovana evropska omladina ulazi u sukob sa etabliranim političkim snagama, i levim i desnim, u cilju prevazilaženja društvene nepravde uzrokovane kapitalizmom. Naime, u perspektivi dela pripadnika ove generacijske skupine, autoritarno i nečovečno nasleđe prošlosti postalo je preteško breme koje je bilo moguće uništiti efektivnom primenom nasilja. Izvore tog društvenog tereta naraštaj „šezdesetosmaša“ prepoznavao je ne samo među baštinicima desničarskih ideja, već i među pripadnicima stare levičarske generacije, grupisane oko komunističkih i/ili socijaldemokratskih partija, koje su u očima mladih levičara bile spremne na "izdaju“ i „kompromis“ sa kapitalizmom. Prema tome, pored desničara, sada su i umereni levičari, oličeni u evropskoj socijaldemokratiji, i radikalni levičari, oličeni u pojedinim komunističkim partijama kapitalističkih zemalja, predstavljali smetnju u ostvarenju pravednijeg društva. Takva društvena klima, obeležena napetošću svojevrsne igre izazova i odgovora, bila je plodno tle za rađanje nove vrste ekstremizma. Pomenuti problem ispitan je na primerima zapadnonemačke „Frakcije Crvene armije“ i italijanskih "Crvenih brigada", koje su se nalazile među najistaknutijim i najpoznatijim grupama tog tipa tokom 70-ih i 80-ih godina. Uočeno je da navedene 
organizacije, kako usled značajnih promena u strukturi kapitalizma $\mathrm{u}$ narečenom periodu, tako i zbog šireg političkog konsenzusa između etablirane desnice i levice, nisu uspele da za svoju delatnost pridobiju masovniju podršku, te su već tokom 80 -ih godina njihove akcije zgasnule $u$ odnosu na prethodnu deceniju, što je predstavljalo neposrednu posledicu odlučnih i žestokih reakcija državnih vlasti. Osim toga, njihovo dejstvo posredno je imalo negativan uticaj na artikulisanje i masovnije prihvatanje nekih radikalnih, ali nenasilnih, levičarskih inicijativa, koje su ubrzo postale dodatno oslabljene nastupanjem epohe neoliberalizma.

Posebna i dramatična prekretnica u razvoju krajnje levice u Evropi obeležena je padom Berlinskog zida i slomom Sovjetskog Saveza, pri čemu su ove krupne geopolitičke promene uzrokovale snažan zaokret epohalne svesti udesno, ostavljajući posledično čitavu levicu na vetrometini udara zdesna. Pod uticajem tih promena, koje su donele trijumf neoliberalizma, levica je bila prinuđena na povlačenje. Prvu odstupnicu načinili su umereni levičari, socijaldemokrati, koji masovno odustaju od reformskog programa prevazilaženja kapitalizma, prelazeći u tabor levih liberala. Istovremeno, dolazi i do preoblikovanja većine starih komunističkih partija, koje neretko gube podršku među biračima i ublažavaju i modifikuju svoje ideološke stavove. Ekstremna levica se našla u znatno težoj situaciji, a trend opadanja njenog relativnog značaja, započet još ranije, nastavljen je još većim intenzitetom, te se ova politička snaga nalazi na potpunoj margini glavnih političkih tokova, mahom tavoreći pod okriljem raznovrsnih anarhističkih, trockističkih ili maoističkih grupica, a veoma blago odstupanje od ovog trenda primetno je gotovo jedino u Grčkoj, Italiji i Španiji. Na drugoj strani, izuzetak u razvoju savremenih evropskih levičarskih politika, čini se, nalazi se samo među onim organizacijama koje su prigrlile demagošku (populističku) strategiju i taktiku osvajanja vlasti. Relativni politički uspeh organizacija poput SYRIZA-e i PODEMOS-a, koje namesto tradicionalnog levičarskog pozivanja na "radničku klasu“ pokušavaju da front svog uticaja prošire na šire društvene slojeve pod parolom "naroda“ , može se tumačiti kao jedna od retkih levičarskih strategija koja ima izgleda na uspeh. Međutim, potrebno je načiniti značajnu ogradu u prethodnom iskazu, budući da su pomenuti izgledi na uspeh izuzetno ograničeni još uvek uspešnim političkim prilagođavanjima kapitalizma, koja se očituju kako kroz delanje „starih“ partija desnog i levog centra, tako i kroz uspon i bujanje krajnje desnice, koja useljeničko pitanje nameće kao centralni politički problem savremene Evrope. Prema tome, iako je izuzetno nezahvalno predviđati dalji rasplet situacije, 
reklo bi se da su šanse za ozbiljnije ugrožavanje neoliberalnog kapitalizma sleva (još uvek) relativno zanemarljive.

\section{Bibliografija}

Bakić, Jovo, Evropska krajnja desnica 1945-2018, Clio, Beograd, 2019.

Chiocchetti, Paolo, The Radical Left Party Family in Western Europe, 1989-2015, Routledge, London and New York, 2017.

Đorić, Marija, Ekstremna levica: ideološki aspekti levičarskog ekstremizma, Institut za političke studije, Beograd, 2016.

Hanshew, Karrin, “'Sympathy for the Devil?' The West German Left and the Challenge of Terrorism", Contemporary European History, Vol. 21, No. 4, 2012, pp. 511-532.

Ili, Džef, Kovanje demokratije: istorija levice u Evropi, 1850-2000, Fabrika knjiga, Beograd, 2007.

Katsambekis, Giorgos and Kioupkiolis, Alexandros, "Introduction: the Populist Radical Left in Europe", in: Giorgos Katsambekis and Alexandros Kioupkiolis (eds), The Populist Radical Left in Europe, Routledge, London and New York, 2019, pp. 1-21.

Kuljić, Todor, Prevladavanje prošlosti: uzroci i pravci promene slike istorije krajem XX veka, Helsinški odbor za ljudska prava u Srbiji, Beograd, 2002.

March, Luke and Mudde, Cas, "What's Left of the Radical Left? The European Radical Left After 1989: Decline and Mutation", Comparative European Politics, No.3, 2005, pp. 23-49.

March, Luke, "Problems and perspectives of contemporary European radical left parties: Chasing a lost world or still a world to win?", International Critical Thought, Vol. 2, No. 3, 2012, pp. 314-339.

Mausbach, Wilfried, "America's Vietnam in Germany - Germany in America's Vietnam", in: Belinda Davis, Wilfried Mausbach, Martin Klimke and Carla MacDougall (eds), Changing the World, Changing Oneself: Political Protest and Collective Identities in West Germany and the U.S. in the 1960s and 1970s, Berghahn Books, New York and Oxford, 2010.

Merari, Ariel, "Terrorism as a Strategy of Insurgency", in: Chaliand Gerard and Blin Arnaud (eds), The history of terrorism: from antiquity to al Qaeda, University of California Press, Berkeley and Los Angeles and London, 2007, pp. 12-51. 
Mudde, Cas, SYRIZA - The Failure of the Populist Promise, Palgrave Macmillan, 2017.

Orsini, Alessandro, Anatomy of the Red Brigades: the religious mind-set of modern terrorists, Cornell University Press, Ithaca and London, 2011.

Ružica, Miroslav, "Kriza i mogućnost obnove evropske socijaldemokratije", u: Zoran Stojiljković, (ur.), Levica u postkriznom kontekstu, Friedrich Ebert Stiftung i Centar za demokratiju, Beograd, 2013, str. 13-22.

Weinberg, Leonard, Pedahzur, Ami \& Perliger, Arie, Political Parties and Terrorist Groups, Routledge, London and New York, 2009.

\section{Nemanja KOSTIĆ}

\section{POSSIBILITIES AND PERSPECTIVES OF THE CONTEMPORARY EUROPEAN FAR-LEFT}

Abstract: The article discusses the role, position and active potential of the farleft groups, organizations and ideas in the context of contemporary European political currents. The introductory paragraph in the presentation offers a theoretical definition for the concept of far-left, based on the structural perspective of Left-Right division. In order to provide a more detailed understanding of the problems from the title, the second part of the paper offers a brief historical overview of the most extreme and violent types of acting and organising within the far-left movements in Europe during the 1970s and 1980s, with reference to some of the most influential and most active groups of that type in the named period, such as the Italian "Red Brigades" (Brigate Rosse) and the West German "Red Army Faction" (Rotte Arme Fraktion). This is followed by the summary of the development and reshaping processes of far-left politics after the fall of the Berlin Wall and the collapse of the Soviet Union. In conclusion, it is pointed out that the mentioned geopolitical breaks and changes, followed by a strong epochal consciousness shift towards the Right, have influenced to the greatest extent almost total marginalisation and passivation of far-left (especially its most extreme wing) in modern European societies, and that the active potential for a serious threat to the neoliberal capitalist order from this ideological-political position is (still) relatively negligible.

Keywords: far-left, right, political extremism, political violence, neoliberal capitalism. 